\title{
Length-Weight Relationships and Condition Factor of Four Different Sea Cucumber Species in the Aegean Sea
}

\author{
Mehmet AYDIN* \\ Fatsa Faculty of Marine Science, Ordu University, Turkey
}

How to cite: Aydın, M. (2020). Length-weight relationships and condition factor of four different sea cucumber species in the Aegean Sea. J. Anatolian Env and Anim. Sciences, 5(1), 80-85.

Atıf yapmak için: Aydın, M. (2020). Ege Denizi’ndeki 4 farklı deniz hıyarı türünün boy-ağırlık ilişkisi ve kondisyon faktörü. Anadolu Çev. ve Hay. Dergisi, 5(1), 80-85.

Abstract: In this study, the gutted length-weight relationships and condition factor of the 4 Holothuria species (Holothuria tubulosa, Holothuria polii, Holothuria mammata and Holothuria sanctori) living in the Aegean Sea were determined.

The sea cucumber samples were obtained between November 2014 and December 2018 by SCUBA and Hookah diving systems in the Aegean Sea. Identification of the species were based on morphometric characteristics only. Total gutted length (GL) and weight (GW) of each individual were recorded with an accuracy $0.1 \mathrm{~cm}$ and $0.01 \mathrm{~g}$, respectively.

*Corresponding author's: Mehmet AYDIN

Fatsa Faculty of Marine Science, Ordu University, 52400 Turkey

$\triangle:$ maydin69@hotmail.com

Mobile telephone : $+90(542) 4356280$

Fax $\quad:+90(452) 4235053$

During the sampling period, a total number of 18248 sea cucumber individuals belonging to four species were collected and measured. Mean gutted length and weight were found to be $13.20 \pm 3.44 \mathrm{~cm}$ and $66.34 \pm 30.93 \mathrm{~g}$ for $H$. tubulosa, $10.45 \pm 2.06 \mathrm{~cm}$ and $49.33 \pm 19.68 \mathrm{~g}$ for H. polii, $13.07 \pm 3.86 \mathrm{~cm}$ and $68.08 \pm 36.73 \mathrm{~g}$ for $H$. mammata, $18.62 \pm 3.02 \mathrm{~cm}$ and $102.34 \pm 21.76 \mathrm{~g}$ for $H$. sanctori, respectively. Negative allometric growth was estimated for all the four species with the " $b$ " values ranging from 1.104 to 1.804 .

Keywords: Holothuria tubulosa, Holothuria polii, Holothuria mammata, Holothuria sanctori length-weight relationship.

\section{Ege Denizi’ndeki 4 Farklı Deniz Hıyarı Türünün Boy-Ağırıı İlişkisi ve Kondisyon Faktörü}

\section{*Sorumlu yazar:}

Mehmet AYDIN

Fatsa Deniz Bilimleri Fakültesi, Ordu Üniversitesi, Ordu/Fatsa 52400, Turkey

凶: maydin69@ hotmail.com

Cep telefonu : $+90(542) 4356280$

Faks : $\quad+90(452) 4235053$
Öz: Bu çalışmada Ege Denizi'ndeki 4 farklı Holothuria türünün (Holothuria tubulosa, Holothuria polii, Holothuria mammata ve Holothuria sanctori) karkas boy ağırlık ilişkileri ve kondisyon faktörleri tespit edilmiştir. Örnekleme Ege Denizi’nde Kasım 2014-Aralık 2018 tarihleri arasında SCUBA veya nargile dalış sistemi ile yapılmıştır. Tür tanımlamaları morfometrik özelliklerine göre yapılmıştır. Total karkas boyu (GL) $0.1 \mathrm{~cm}$ ve total ağırlığ $(\mathrm{GW})$ $0.01 \mathrm{~g}$ hassasiyetle ölçülmüştür. Dört türe ait toplam 18248 adet birey örneklenmiş ve ölçülmüşsür. $H$. tubulosa için ortalama karkas boyu $13.20 \pm 3.44 \mathrm{~cm}$ ve ortalama karkas ağırlığ 1 $66.34 \pm 30.93 \mathrm{~g}$ olarak, $H$. polii için $10.45 \pm 2.06 \mathrm{~cm}$ ve $49.33 \pm 19.68 \mathrm{~g}$ olarak, H.mammata için $13.07 \pm 3.86 \mathrm{~cm}$ ve $68.08 \pm 36.73 \mathrm{~g}$ olarak, $H$. sanctori için $18.62 \pm 3.02 \mathrm{~cm}$ ve $102.34 \pm 21.76 \mathrm{~g}$ olarak hesaplanmıştır. Büyüme her dört türde de negatif allometrik, $b$ değerleri de 1.104 to 1.804 arasında olduğu tespit edilmiştir.

Anahtar kelimeler: Boy-ağırlık ilişkisi, Holothuria tubulosa, Holothuria polii, Holothuria mammata, Holothuria sanctori.

\section{INTRODUCTION}

Sea cucumbers are very important component of the marine ecosystems, because they play a crucial role in the detritus food chain and are implied in the recycling of organic matter by ingestion of sediment (Massin, 1982; Zupo 
\& Fresi, 1984; Francour, 1990; Belbachir et al., 2019). Approximately 1200 known sea cucumber species exist in the world oceans (Conand, 1990), while 66 of them are commercially exploited (Purcell, 2010). Sea cucumbers are harvested and traded in more than 70 countries worldwide (Purcell et al., 2012). Sea cucumber species (Holothuria tubulosa Gmelin 1790, Holothuria polii Delle Chiaje 1823, Holothuria mammata Grube 1840, Stichopus regalis Cuvier, 1817) from Mediterranean Sea are commercial target species of fisheries since 1990s (Aydın, 2008). Recently, Turkey acquired a leading position among Mediterranean countries in the exports of sea cucumbers, the latter being widely distributed across its Aegean coasts. A considerable increase in the Sea cucumber fishery of Turkey has been observed since 1996. The average of past seven years was 419 ton, 2017 production was approximately 855 ton (Aydin, 2017; TURKSTAT, 2018).

Length-weight relationships are used in fisheries management. The main objective of this study was to determine of gutted length-weight relationship and condition factor of four sea cucumbers species: H. tubulosa, $H$. polii, H. mammata and H. sanctori Delle Chiaje, 1823 in the coastal waters of the Aegean Sea.

\section{MATERIAL AND METHOD}

The Aegean Sea is the only area where the sea cucumber stocks are abundant in Turkey's territorial waters and the only field where harvesting is legal. The region is divided into two sub-regions, harvesting is permitted 4 years in the northern part, 4 years in the southern part (Aydin, 2019a). This study was conducted in this commercially exploited area (Figure 1).

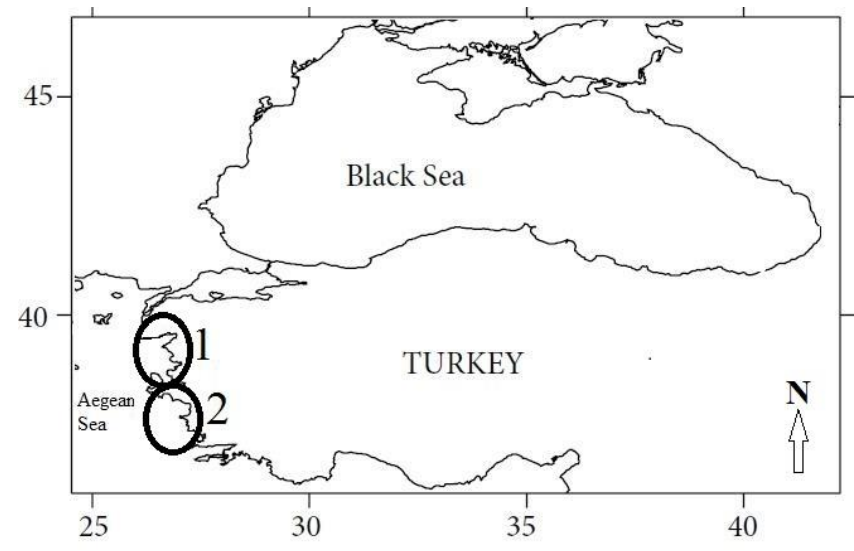

Figure 1. Sampling area.

Individuals of sea cucumber species were sampled between November 2014 and December 2018 by SCUBA and Hookah diving systems in the Aegean Sea (Fig. 1) which is actually a large data set obtained by the Republic of Turkey Ministry of Agriculture and Forestry for the purpose of stock management.
Individuals of sea cucumber species were sampled between November 2014 and December 2018 by SCUBA and Hookah diving systems in the Aegean Sea (Fig. 1) which is actually a large data set obtained by the Republic of Turkey Ministry of Agriculture and Forestry for the purpose of stock management.

Identification of the species was based only on morphometric characteristics (Aydın \& Erkan, 2015). Due to its abilities to take water and release it, expel internal organs, extraction or relaxation, the size and weight of the sea cucumber can vary during morphometric measurements (Aydın et al., 2011; Gonzalez-Wangüemert et al., 2014; Aydın, 2019a; Aydın, 2019b). In addition, being alive or dead also causes changes in length. Therefore, the sea cucumber must be kept alive in the seawater until the internal organs are removed. During measurements a small longitudinal incision $(3 \mathrm{~cm})$ was done on the abdominal area, the internal organs were removed, and weight $(\mathrm{GW})$ was measured. After the internal organs are emptied, the individual is suspended in seawater for 30-60 seconds and the length becomes more stable. Because of this characteristic, GW and length (GL) measurements were carried out within one minute after the internal organs were removed. Total gutted (removal of alimentary canal, gonads, and respiratory trees) GL and GW of each individual were recorded with an accuracy of $0.01 \mathrm{~cm}$ and $0.01 \mathrm{~g}$, respectively. The GL-GW relationships were determined for all collected individuals by $\mathrm{GW}=\mathrm{aGL}^{\mathrm{b}}$ equation, where $\mathrm{GW}$ is weight $(\mathrm{g}), \mathrm{GL}$ is length $(\mathrm{cm})$ and " $\mathrm{a}$ " and " $\mathrm{b}$ " are the Coefficients of the function obtained from regression between GW and GL (Ricker, 1975). The "b" value was tested by t-test to check whether it was significantly different from 3 . When $b=3$, it reflects an isometric growth, when it is $b \neq 3$ it reflects an allometric growth (positive $b>3$ or negative $b<3$ ) (Froese, 2006).

Fulton's coefficient of condition factor $(\mathrm{K})$ was calculated by $\mathrm{K}=100 * \mathrm{GW} / \mathrm{GL}^{3}$ equation, where $\mathrm{GL}$ is length (cm) and GW is weight (g) (Le Cren, 1951; Bagenal, 1978; Sparre \& Venema, 1992; Froese, 2006).

The relationships among the variables were identified using the regression analysis. The best appropriate model was selected based on $\mathrm{R}^{2}$ value. The observed differences were evaluated statistically using SPSS 22.0 and Student's t-test (Sokal \& Rohlf, 1969; Düzgüneş et al., 1983).

\section{RESULTS}

During the sampling period, a total of 18248 individuals of sea cucumber belonging to four species were collected and measured. While number of individuals was maximum in $H$. polii (9086), minimum number of individuals (747) was obtained in H. sanctori. H. sanctori is 
also found to be the species showing the highest gutted length and weight. Morphometric description of the data-set used in the length-weight relationship is summarized in Table 1.

Table 1. Summary of the gutted length (GL)-gutted weight (GW) data from each species.

\begin{tabular}{|c|c|c|c|c|c|}
\hline & & GL (cm) & & GW (g) & \\
\hline Species & $\mathbf{N}$ & Mean \pm SE & Min-Max & Mean \pm SE & Min-Max \\
\hline H. tubulosa & 6414 & $13.20 \pm 3.44$ & $4-27.3$ & $66.34 \pm 30.93$ & $7.4-225.0$ \\
\hline H. polii & 9086 & $10.45 \pm 2.06$ & $3.4-18.0$ & $49.33 \pm 19.68$ & $6.9-135.0$ \\
\hline H. mammata & 2001 & $13.07 \pm 3.86$ & $3.8-27.6$ & $68.08 \pm 36.73$ & $3.5-230.0$ \\
\hline H. sanctori & 747 & $18.62 \pm 3.02$ & $9.0-26.9$ & $102.34 \pm 21.76$ & $33-185.9$ \\
\hline Total & 18248 & & & & \\
\hline
\end{tabular}

R-squared coefficients of power regression, which is used for modeling in this study, were found ranged between 0.752 and 0.890 for the length-weight relationships. These models were estimated as $\mathrm{GW}=0.779 \mathrm{GL}^{1.702}\left(\mathrm{R}^{2}=0.833\right)$ for $H$. tubulosa, $\mathrm{GW}=0.682 \mathrm{GL}^{1.804}\left(\mathrm{R}^{2}=0.712\right)$ for $H$. polii, $\mathrm{GW}$ $=0.717 \mathrm{GL}^{1.752}\left(\mathrm{R}^{2}=0.890\right)$ for $H$. mammata and $\mathrm{GW}=$ $4.029 \mathrm{GL}^{1.104}\left(\mathrm{R}^{2}=0.752\right)$ for $H$. sanctori. Negative allometric growth was observed for all the four species (Table 2). The weight-length relationship graphics of $H$. tubulosa, $H$. polii, $H$. mammata and $H$. sanctori are given in Figure 2.

Table 2. Regression parameters of the GL-GW relationship $\left(\mathrm{GW}=\mathrm{aGL}{ }^{\mathrm{b}}\right)$ of the 4 sea cucumbers.

\begin{tabular}{|c|c|c|c|c|c|c|c|}
\hline \multirow[b]{2}{*}{ Species } & \multirow[t]{2}{*}{$\mathbf{N}$} & \multicolumn{5}{|c|}{$\mathbf{G W}=\mathrm{aGL}^{\mathrm{b}}$} & \multirow{2}{*}{$\begin{array}{l}\text { Significant } \\
\text { Level } \\
\text { Pauly's t- } \\
\text { testi }\end{array}$} \\
\hline & & $\mathbf{a}$ & b & SE(b) & CI(b) & $\mathbf{R}^{2}$ & \\
\hline H. tubulosa & 6414 & 0.779 & 1.702 & 0.009 & $1.68-1.72$ & 0.833 & $\begin{array}{l}\mathrm{t}=136.3 \\
(\mathrm{P}<0.05)\end{array}$ \\
\hline H. polii & 9086 & 0.682 & 1.804 & 0.012 & $1.78-1.82$ & 0.712 & $\begin{array}{l}\mathrm{t}=100.2 \\
(\mathrm{P}<0.05)\end{array}$ \\
\hline H.mammata & 2001 & 0.717 & 1.752 & 0.012 & $1.74-1.78$ & 0.890 & $\begin{array}{l}\mathrm{t}=90.8 \\
(\mathrm{P}<0.05)\end{array}$ \\
\hline H. sanctori & 747 & 4.029 & 1.104 & 0.023 & $1.05-1.15$ & 0.752 & $\begin{array}{l}\mathrm{t}=81.5 \\
(\mathrm{P}<0.05)\end{array}$ \\
\hline
\end{tabular}

determination, $\boldsymbol{C I}$ : $95 \%$ confidence interval.
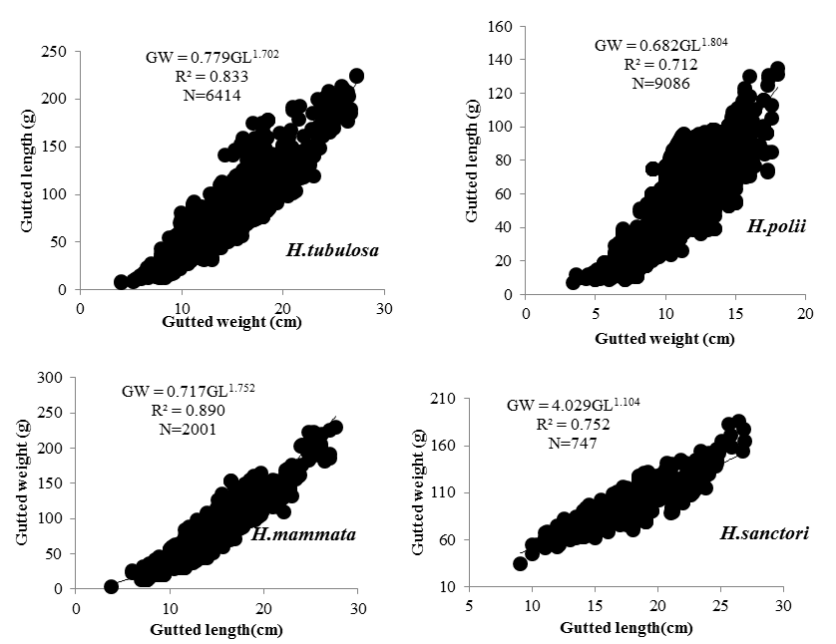

Figure 2. GL-GW relationship for H. tubulosa, H. polii, $H$. mammata and $H$. sanctori.

In the study, the $\mathrm{K}$ values of the species were also investigated, and the highest $\mathrm{K}$ value was observed for $H$. polii (4.45), and the lowest for $H$. sanctori (1.73). The average, minimum, and maximum $\mathrm{K}$ values for each of the four species are given in Table 3.

Table 3. Fulton's coefficient of condition factor $(\mathrm{K})$ for the four sea cucumber species in the Aegean Sea.

\begin{tabular}{lccccc}
\hline \multicolumn{5}{c}{ K=100GW/GL } & \\
\hline & $\mathbf{N}$ & Mean $(\mathbf{K})$ & \pm SE & Minimum & Maximum \\
\hline H. tubulosa & 6414 & 3.07 & 1.18 & 1.0 & 13.0 \\
H. polii & 9086 & 4.45 & 1.53 & 1.4 & 17.6 \\
H.mammata & 2001 & 3.25 & 1.09 & 0.9 & 12.0 \\
H. sanctori & 747 & 1.73 & 0.71 & 0.8 & 5.5 \\
\hline
\end{tabular}

When the $\mathrm{K}$ values were evaluated in relation to GL, there were abnormal fluctuations in the graph because the number of individuals in the 4-8 cm length group was low. It is possible to say that $\mathrm{K}$ values of all four species individuals larger than $8 \mathrm{~cm}$ are similar (Figure 3 ).

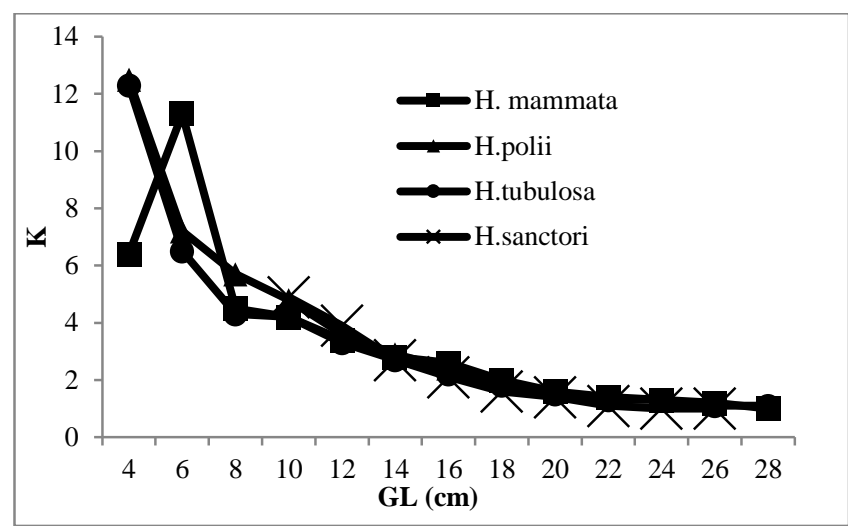

Figure 3. Relationships between condition factor $(K)$ and GL $(\mathrm{cm})$ for four species.

\section{DISCUSSION}

The weight-length relationships and Fulton's condition factor are two main parameters used in fisheries management (Froese, 2006). The studies in the Aegean Sea related to the weight-length relationships are summarized in Table 4. The "b" values of the previous studies reported negative allometric growth (except for GonzálezWangüemert et al., 2016) for the species. Similarly, Veronika et al., (2018) stated that negative allometric growth for 4 different species in the coasts of Sri Lanka. Negative allometry was also reported from a study by Venkataraman (2007) from India. It is known that, when "b" value is smaller than 3 it means that the species show negative allometry and it's a lean, long and flat bodied (Pauly, 1983). When morphometric structure of the species is considered, it is normal to estimate the " $b$ " value less than 3 . Though there were many different methodologies used to measure $\mathrm{L}$ and $\mathrm{W}$ in Table 4, the average weight of $H$. tubulosa from this study was $66.51 \mathrm{~g}$, Dereli et al., (2016) reported as $49.9 \mathrm{~g}$, González-Wangüemert et al., (2014) reported as $88.7 \mathrm{~g}$, González-Wangüemert et al., (2016) reported as $83.8 \mathrm{~g}$, Kazanidis et al., (2010) reported as 108.4 g, Vafeiadou et al., 
(2010) reported as $61.8 \mathrm{~g}$, Aydin \& Erkan (2015) reported as 83.7 g, and Aydın \& Emre (2009) reported as 78.62 g.

The average weight of $H$. polii was higher in every previous study (except Aydın \& Emre, 2009). The study conducted by Aydin \& Emre (2009) did not calculated average GW, but wet weight. The average $\mathrm{GW}$ of $H$. mammata was $68.08 \mathrm{~g}$ in the study. In other studies, it was reported as $88.5 \mathrm{~g}$ (González-Wangüemert et al., 2016), 109.0 g (González-Wangüemert et al., 2014), $23.0 \mathrm{~g}$ (Navarro et al., 2013), $109.8 \mathrm{~g}$ (Aydın \& Erkan, 2015), 105.9 g (Aydın \& Emre, 2009). It can be said that the differences are the result of regional differences or using different measurements.

The average weight of $H$. sanctori in this study was higher than previously reported weights (Table 4). It was observed that $H$. sanctori was the heaviest among the four commercial sea cucumbers. Even though the meat ratio of this species is higher more compared to other species, it is not commercially used in Turkey. The reason for this is that the species have cuvier organs, that, when threatened releases a web of tubulars with very adhesive secretion to the environment. This defensive mechanism of web of secretion is powerful enough to neutralize a fish or a crab, therefore, the area becomes very sticky and makes it impossible for harvest or storage (Aydın, 2013).

$\mathrm{K}$ is used to compare the wellbeing of an organism and the health of the environment (Pauly, 1983). The average $\mathrm{K}$ values of four species (H.tubulosa, H. polii, H. mammata and $H$. sanctori) were estimated between $1.73-4.45$. The study on four different species (H. spinifera, B. marmorata, $S$. naso and H. atra) by Veronika et al., (2018) reported similar values, between 2.688-4.125. These values indicate that the species are in good physical condition.

Turkey is the most commercial sea cucumber producing country in the Mediterranean Basin (Aydin 2019a). Average sea cucumber production for the last seven years was 419-ton/yr and the total production of 2017 was approximately 855 tons (Aydın, 2017; TURKSTAT, 2018). Sea cucumber harvest has an increasing trend in the world, and due to high fishing pressure, natural stocks are faced with the threat of rapid collapse. It is reported that there is no decline in the commercial sea cucumber stocks in Turkish waters (Aydin, 2019a). The length and weight values obtained in this study supports this concept.

Table 4. Comparison of WLRs parameters, minimum and maximum length weight from different geographical areas.

\begin{tabular}{|c|c|c|c|c|c|c|c|c|}
\hline & $\mathbf{N}$ & Mean GL (cm) & Mean GW (g) & $\mathbf{a}$ & b & $\mathbf{R}^{2}$ & Locations & References \\
\hline Species & & Min-Max & Min-Max & & & & & \\
\hline H. tubulosa(GL-GW) & 6414 & $13.26(4-27.3)$ & $66.51(7.4-225)$ & 0.779 & 1.702 & 0.833 & Aegean Sea & This Study \\
\hline H. polii (GL-GW) & 9086 & $10.45(3.4-18.0)$ & 49.33(6.9-135.0) & 0.682 & 1.804 & 0.712 & Aegean Sea & This Study \\
\hline H.mammata (GL-GW) & 2001 & $13.07(3.8-27)$ & $68.08(3.5-230)$ & 0.717 & 1.752 & 0.890 & Aegean Sea & This Study \\
\hline H. sanctori (GL-GW) & 747 & $18.62(9-26.9)$ & $102.34(33-185.9)$ & 4.029 & 1.104 & 0.752 & Aegean Sea & This Study \\
\hline H. polii(L-EW) & 312 & $16.7(10.4-25.4)$ & $47.3(19.8-79.1)$ & 17.4 & 1.77 & 0.14 & NE Atlantic, Med. & González-Wangüemert et al., (2016) \\
\hline H. tubulosa(L-EW) & 282 & $20.7(12.2-30.9)$ & $83.8(25.0-159.5)$ & -3.8 & 4.3 & 0.38 & NE Atlantic, Med. & González-Wangüemert et al., (2016) \\
\hline H.mammata(L-EW) & 298 & $21.2(12.4-33.5)$ & $88.5(38.0-160.8)$ & -31.0 & 5.62 & 0.41 & NE Atlantic, Med. & González-Wangüemert et al., (2016) \\
\hline H. polii(EL-EW) & 839 & $10.5(6.5-18.2)$ & $37.5(17-84)$ & 3.10 & 1.05 & 0.45 & Aegean Sea & González-Wangüemert et al., (2014) \\
\hline H. tubulosa(EL-EW) & 754 & $16.4(8-26)$ & $88.7(30-211)$ & 3.45 & 1.14 & 0.41 & Aegean Sea & González-Wangüemert et al., (2014) \\
\hline H.mammata(EL-EW) & 422 & $17(10-28)$ & $109.0(30-210)$ & 6.2 & 1.00 & 0.52 & Aegean Sea & González-Wangüemert et al., (2014) \\
\hline H.mammata & 280 & & 23.4 & & & & Gran Canaria Island & Navarro et al. (2013) \\
\hline H. sanctori & 2032 & & 18.1 & & & & Gran Canaria Island & Navarro et al. (2013) \\
\hline H. tubulosa(L-EW) & 314 & $29.8(13.8-49.4)$ & $108.4(39.4-226.3)$ & 6.71 & 0.81 & 0.58 & Aegean Sea & Kazanidis et al. (2010) \\
\hline H. tubulosa & 350 & $10.26(4.3-19.7)$ & $61.8(20.3-164.4)$ & & & & Aegean Sea & Vafeiadou et al. (2010) \\
\hline H. sanctori(EL-EW) & 340 & $18.1(11-25)$ & $100.5(51-175.7)$ & 2.320 & 1.29 & 0.72 & Aegean Sea & Aydin (2013) \\
\hline H. polii(Wet W) & 1558 & & 46.3 & & & & Aegean Sea & Aydın and Erkan (2015) \\
\hline H. tubulosa(Wet W) & 1288 & & 83.7 & & & & Aegean Sea & Aydın and Erkan (2015) \\
\hline H.mammata(Wet W) & 498 & & 109.8 & & & & Aegean Sea & Aydnn and Erkan (2015) \\
\hline H. polii(Wet W) & 618 & & $59.25(9.2-264)$ & & & & Aegean Sea & Aydin and Emre (2009) \\
\hline H. tubulosa(Wet W) & 434 & & $78.62(3-246.2)$ & & & & Aegean Sea & Aydin and Emre (2009) \\
\hline H.mammata $($ Wet $\mathrm{W})$ & 28 & & $105.9(25.1-167.2)$ & & & & Aegean Sea & Aydın and Emre (2009) \\
\hline
\end{tabular}

GL: Gutted length, GW: Gutted weight, L: Length, EL: Eviscerated length, EW: Eviscerated weight.

\section{CONCLUSIONS}

In conclusion, base data required for maximum usage of sea cucumber stocks in a sustainable perspective, such as length-weight relationship and condition factor were obtained during this study. The data obtained in this study are very important for the stock management of these species, which are exploited and are important part of the marine ecosystem. Therefore, this data is made available to the relevant institutions for the management of stocks in the region.

\section{ACKNOWLEDGEMENTS}

This research was supported by the Ordu University Scientific Research Coordination Unit with the project No. AR-1501 


\section{REFERENCES}

Aydın, M. (2008). The Commercial sea cucumbers fishery in Turkey. SPC Beche de mer Information Bulletin, 28, 40-43.

Aydın, M. \& Emre, Y. (2009). Determination of the sea cucumber stock between Ayvalık and Çeşme. Project final report. Ministry of Agriculture and Rural Affairs TAGEM. TAGEM/HAYSÜD/ 2007/09/01/01. 50p.

Aydın, M. (2013). Some biological characteristics of the sea cucumber Holothuria (Platyperona) sanctori Delle Chiaje, 1823 (Echinodermata: Holothuroidea). Biological Diversity and Conservation, 6(3), 153-159.

Aydın, M. (2017). Present status of the sea cucumber fishery in Turkey. SPC Beche de Mer Information Bulletin, 37, 30-34.

Aydın, M. (2019a). Biometry, density and the biomass of the commercial sea cucumber population of the Aegean Sea. Turkish Journal of Fisheries and Aquatic Sciences, 19(6), 463-474. DOI: 10.4194/1303-2712-v19_6_02.

Aydın, M. (2019b). Density and biomass of commercial sea cucumber species relativeto depth in the Northern Aegean Sea. Thalassas: An International Journal of Marine Sciences, 35(2), 541-550. DOI: 10.1007/s41208-019-00144-4.

Aydın, M. \& Erkan, S. (2015). Identification and some biological characteristics of commercial sea cucumber in the Turkey coast waters. International Journal of Fisheries and Aquatic Studies, 3(1), 260-265.

Aydın, M., Sevgili, H., Tufan, B., Emre, Y. \& Köse, S. (2011). Proximate composition and fatty acid profile of three different fresh and dried commercial sea cucumbers from Turkey. International Journal of Food Science \& Technology 46(3), 500-508. DOI: 10.1111/j.1365-2621.2010.02512.x.

Bagenal, T.B. (1978). Methods for Assessment of Fish Production in Fresh Waters. 3rd ed., Handbook No:3, Blackwell Scientific Publication, Oxford, $365 \mathrm{p}$.

Belbachir, N.E., Lepoint, G. \& Mezali, K. (2019). Comparison of isotopic niches of four sea cucumbers species (Holothuroidea: Echinodermata) inhabiting two seagrass meadows in the southwestern Mediterranean Sea (Mostaganem, Algeria). Belgian Journal of Zoology, $\quad \mathbf{1 4 9}(1), \quad 95-106 . \quad$ DOI: 10.26496/bjz.2019.32.
Conand, C. (1990). The fishery resources of Pacific island countries. Part 2: Holothurians. FAO Fisheries Technical Paper. No. 272. Rome. 143 p.

Dereli, H., Culha, S.T., Culha, M., Özalp, B.H. \& Tekinay, A.A. (2016). Reproduction and population structure of the sea cucumber Holothuria tubulosa in the Dardanelles Strait, Turkey. Mediterranean Marine Science, 17(1), 47-55. DOI: $10.12681 / \mathrm{mms} .1360$.

Düzgüneş, O., Kesici, T. \& Gürbuz, F. (1983). Statistic Methods I, Ankara University, Faculty of Agriculture press, Ankara, 295p.

Francour, P. (1990). Dynamique de l'écosystème à Posidonia oceanica dans le parc national de Port Cros. Analyse des compartiments matte, litière, faune vagile, échinodermes et poissons. Thèse de Doctorat, Univ. P. et M. Curie, Paris. 1-373.

Froese, R. (2006). Cube law, condition factor and weightlength relationships: History, meta-analysis and recommendations. Journal of Applied Ichthyology, 22, 241-253. DOI: 10.1111/j.14390426.2006.00805.x.

González-Wangüemert, M., Aydın, M. \& Chantal, C. (2014). Assessment of sea cucumber populations from Aegean Sea (Turkey): First insights to sustainable management of new fisheries. Ocean \& Coastal Management, 92, 87-94. DOI: 10.1016/j.ocecoaman.2014.02.014.

González-Wangüemert, M., Valente, S., Henriques, F., Domínguez-Godino, J.A. \& Serrãoa, E.A. (2016). Setting preliminary biometric baselines for new target sea cucumbers species of the NE Atlantic and Mediterranean fisheries. Fisheries Research, 179, 57-66. DOI: 10.1016/j.fishres.2016.02.008.

Kazanidis, G., Antoniadou, C., Lolas, A.P., Neofitou, N., Vafidis, D., et al. (2010). Population dynamics and reproduction of Holothuria tubulosa (Holothuroidea: Echinodermata) in the Aegean Sea. Journal of the Marine Biological Association of the United Kingdom, 90(05), 895901. DOI: 10.1017/S0025315410000251.

Le Cren, E.D. (1951). The length-weight relationship and seasonal cycle in gonad weight and condition in the perch (Perca fluviatilis). Journal of Animal Ecology, 20, 201-219.

Massin, C. (1982). Food and feeding mechanisms, Holothuroidea. In: Jangoux, M. et al. (Ed.) Echinoderm nutritin. Rotterdam, The: pp. 43-55.

Navarro, P.G., García-Sanz, S., \& Tuya, F. (2013). Patrones de abundancia y talla de Holothuria sanctori, Holothuria mammata y Holothuria arguinensis (Echinodermata: Holoturoidea) en la 
isla de Gran Canaria, Atlántico oriental. Revista de Biología Marina y Oceanografía, 48(2), 273284. DOI: $10.4067 /$ S0718-19572013000200007.

Pauly, D. (1983). Some simple methods for the assessment of tropical fish stocks. FAO Fish. Tech. Pap. (234), 52p.

Purcell, S.W. (2010). Managing sea cucumber fisheries with an ecosystem approach. Edited/compiled by Lovatelli, A., Vasconcellos, M., Yimin, Y., FAO Fisheries and Aquaculture Technical Paper. No:520. Rome, FAO.157p.

Purcell, S.W., Samyn, Y. \& Conand, C. (2012). Commercially Important Sea Cucumbers of the World. FAO Species Catalogue for Fishery Purposes. No: 6. FAO, Rome,150p.

Ricker, W.E. (1975). Computation and interpretation of biological statistics of fish populations. Bulletin Fisheries Research Board of Canada, 191, 1-382.

Sokal, R.R. \& Rohlf, F.J. (1969). Introduction to Biostatistics, Second Edition, W.H. Freeman and Company, New York.

Sparre, P. \& Venema, S.C. (1992). Introduction to Tropical Fish Stock Assessment, Part I, FAO Fisheries Technical Paper 306/1, Rome, 376p.
TURKSTAT. (2018). "Sea cucumber trade". Turkish Statistical Institute. Ankara. www.tuik.gov.tr.

Vafeiadou, A.M., Antoniadou, C., Vafidis, D., Fryganiotis, K. \& Chintiroglou, C. (2010). Density and biometry of the exploited holothurian Holothuria tubulosa at the dodecanese, South Aegean sea. Rapport Commission international Mer Méditerranée, 39, 661.

Venkataraman, C. (2007). Present status of population of holothurians in India. FAO-BOBLME. pp. 58

Veronika, K., Edrisinghe, U., Sivashanthini, K. \& Athauda, A.R.S.B. (2018). Length-weight relationships of four different sea cucumber species in North-East coastal region of Sri Lanka. Tropical Agricultural Research, 29(2), 212-217. DOI: https://doi.org/10.4038/tar.v29i2.8290.

Zupo, V. \& Fresi, E. (1984). A study on the food web of Posidonia oceanica ecosystem. Analysis of the gut contents of Echinoderms. In: Boudouresque, C.F., Jeudy de Grissac, A., Olivier, J. (eds), First International workshop on Posidonia oceanica Beds, Gis Posidonie publ., Fr. 1, 373-379. 